\title{
RADIOCARBON DATING ORGANIC DETRITUS: IMPLICATIONS FOR STUDYING ICE SHEET DYNAMICS
}

\section{JAAN-MATI PUNNING}

Institute of Ecology, Estonian Academy of Sciences, Kevada 2, EE-0001 Tallinn, Estonia

and

\section{RAIVO RAJAMÄE}

Institute of Geology, Estonian Academy of Sciences, Estonia 7, EE-0001 Tallinn, Estonia

\begin{abstract}
We present here a description of the ${ }^{14} \mathrm{C}$ dating method used at the Institute of Geology, Estonian Academy of Science. We discuss results of geochronological studies of several stratigraphic sections, from which we estimate the age of the Late Weichselian (Late Valdaian) glacial maximum. ${ }^{14} \mathrm{C}$ and paleobotanical data indicate that biodetrital materials comprise organic debris from various sources and suggest only a maximum age of investigated strata (16,000 BP).
\end{abstract}

\section{INTRODUCTION}

Radiocarbon dating of the dynamics of continental and mountain glaciation is hindered by the absence of suitable material for reliable dating. Complex sedimentary conditions in front of a retreating or advancing glacial massif generally prevent the formation of organic sediments, as well as the preservation of primary sedimentary structure. Thus, despite extensive research, there is still much controversy regarding the dynamics of the Scandinavian glacial shield during the second half of the Late Pleistocene. We present here data for the age of the Late Weichselian (Late Valdaian) glacial maximum on the East European Plain in northern Belorussia and the Vologda District (Figs. $1,2)$.

\section{METHODS}

We prepared ${ }^{14} \mathrm{C}$ samples using standard pretreatment methods. Because the organic material was dispersed, we concentrated it by washing the samples in a sieve. Calcareous and humic intrusions were separated from the concentrated organic matter by successive treatment of samples with $5 \%$ $\mathrm{HCl}, 0.1 \mathrm{~N} \mathrm{Na}_{4} \mathrm{P}_{2} \mathrm{O}_{7}+2 \% \mathrm{NaOH}$ and $5 \% \mathrm{HCl}$. Residue was dried, then synthesized to benzene (Ilves, Liiva and Punning 1974). For small samples, we diluted sample $\mathrm{CO}_{2}$ by combustion with $\mathrm{CO}_{2}$ obtained from the background preparation (Rajamäe and Putnik 1981).

${ }^{14} \mathrm{C}$ activity was determined using a partly homemade anticoincidence liquid scintillation counter. The active shield consists of a plastic scintillator and a passive shield with a thickness of $2.5 \mathrm{~cm}$ $\mathrm{Hg}$ and $15 \mathrm{~cm} \mathrm{~Pb}$. The mean ${ }^{14} \mathrm{C}$ counting efficiency is $55 \%$, and background is reduced $50-85 \%$ by the active shield (depending on the volume of the measured preparation).

A number of corrections were introduced to increase measurement precision. Background was corrected barometrically $\left(2.8 \% \mathrm{~cm}^{-1}\right.$ of the $\mathrm{Hg}$ column). Activity was corrected according to the scintillation efficiency determined with an external source $\left({ }^{137} \mathrm{Cs}\right)$. Sample weight was determined before and after the measuring cycle. Background and standard statistical errors used in age calculations were obtained by analyzing results of repeated measurements. Table 1 presents maximum sample ages (yr BP) that can realistically be determined on our instrument, depending on the amount of carbon measured. 
TABLE 1. Scintillation Counter Characteristics

\begin{tabular}{lcll}
\hline \multirow{2}{*}{$\begin{array}{l}\text { Carbon } \\
\text { amount }(\mathrm{g})\end{array}$} & $\begin{array}{c}\text { Background value } \\
(\mathrm{dpm})\end{array}$ & \multicolumn{2}{c}{ Maximum age (yr BP) } \\
\cline { 3 - 4 } & $0.20 \pm 0.02$ & $48 \mathrm{~h}, 2 \mathrm{\sigma}$ & $96 \mathrm{~h}, 2 \mathrm{\sigma}$ \\
\hline 0.83 & $0.67 \pm 0.03$ & 45,400 & 43,100 \\
4.05 & $1.40 \pm 0.03$ & 50,800 & 58,100 \\
8.10 & $1.65 \pm 0.04$ & 53,800 & 56,600 \\
12.15 & $2.11 \pm 0.04$ & 57,000 & 59,700 \\
20.25 &
\end{tabular}

\section{THE STRATIGRAPHIC SECTIONS}

The age of Late Weichselian (Valdaian) glaciation on the East European Plain is a topic of current debate, and has not been resolved by ${ }^{14} \mathrm{C}$ dating. We discuss the few available sections that illustrate questions regarding the dynamics of Late Weichselian glaciation. These are seen mainly in two regions: North Belorussia and the Vologda District (Figs. 1, 2).

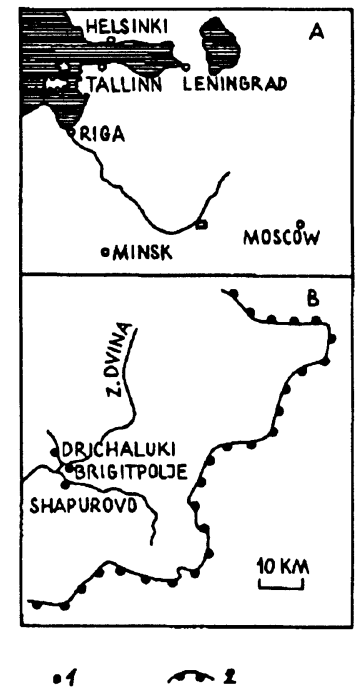

Fig. 1. A. Location sketch map. B. Sketch map of area investigated in North Belorussia; 1. Geological section investigated; 2 . Ice boundary of maximum stage (Chebotareva 1977)

\section{North Belorussia}

This area, of interest to Quaternary researchers since the 1930s, forms the basis for the entire Late Pleistocene chronology (Voznyachuk 1972; Chebotareva and Makarycheva 1974; Arslanov 1987). In the upper reaches of the Zapadnaya Dvina (Daugava) River, the discharge area of the Usvyachy River extends over a large limnoglacial plain between two moraine belts; the belts correspond to the maximum extent of Late Pleistocene glaciation in that area. At the retreating glacial front, a huge system of ice lakes formed, where complicated erosional and accumulative processes occurred. They are reflected in the deposition of sediments in the study areas; thin layers of washed 
till alternate with layers of sand, aleurite and organic detritus, the texture of which indicate intricate cryogenic and mechanical secondary influences.

The type section is at Chapurovo on the bank of the Kasplya River. According to paleobotanical studies (Arslanov et al. 1971), a complex of lacustrine-alluvial deposits formed during severe climatic conditions, and is documented by underlying till and glacial sediments. The occurrence of pollen of thermophilic species suggests resedimentation.

Plant remains from lacustrine-alluvial sediments $0.4-0.6 \mathrm{~m}$ thick yielded ${ }^{14} \mathrm{C}$ dates in the interval 22-36 ka BP; the dates increase regularly with depth (Arslanov et al. 1971). Our date, 31,550 \pm 350 (Tln-88), falls within this range. The structure of the section leaves some doubt as to the reliability of the dates, especially because of such a low apparent accumulation rate.

We studied the Drichaluky section on the Usvyachy River (Fig. 3). Here, the lacustrine-alluvial Usvyachy sediment complex is overlain by loamy till, which is, in turn, overlain by limnoglacial deposits. Syngenetic cryogenic deformation can be traced in the upper part of the Usvyachy site. Interlayers of organic detritus are clearly observed in the lacustrine-alluvial sediments. Below, the visible part of the section ends with brown till.

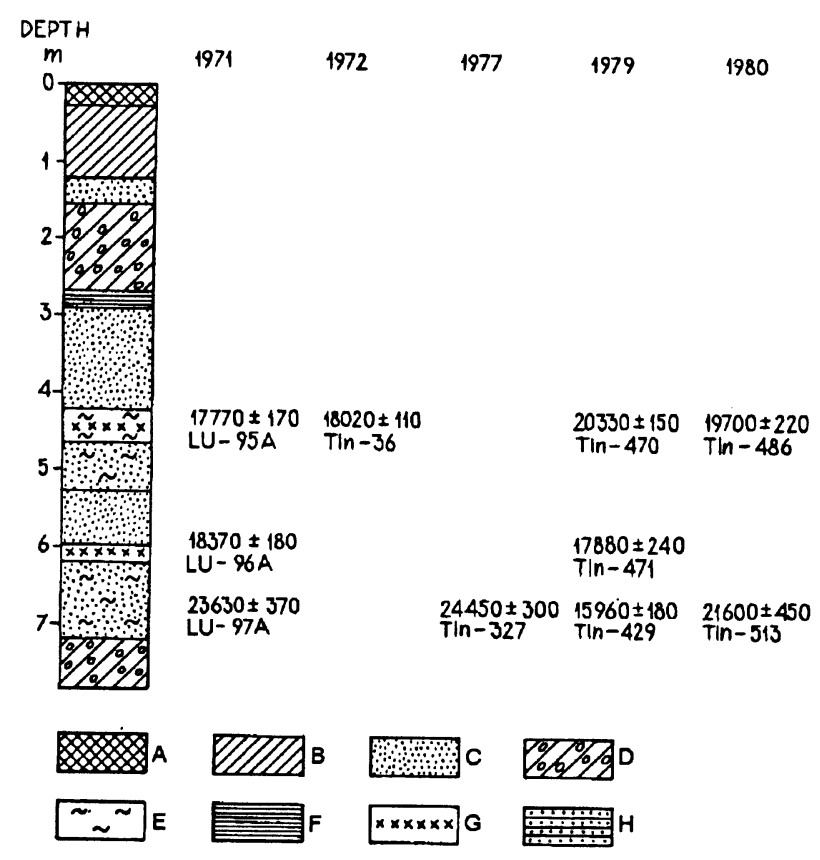

Fig. $3 .{ }^{14} \mathrm{C}$ dates from the Drichaluky section. A. recent soil; B. silt; C. sand; D. till; E. sandy loam; F. laminated clay; G. plant remains; H. fine-grained sand.

Initial ${ }^{14} \mathrm{C}$ dates of organic detritus from the layers at 120,170 and $280 \mathrm{~cm}$ from the upper stratum of varved clay were measured by Arslanov et al. (1971). On the basis of geological, paleobotanical and ${ }^{14} \mathrm{C}$ studies, they concluded that the last glacial maximum was ca. $17 \mathrm{ka}$ BP. However, we doubt this conclusion, because the Drichaluky section is $60 \mathrm{~km}$ north of the end moraine, and it is difficult to account for such a rapid retreat of the glacial front. Also, Velichkevich (in Arslanov et al. 1971) divided the fossil flora into six groups (hypoarctic species, heliophytes, water-bog plants, flora of taiga and mixed forests, thermophilic and exotic species, neogenic and Devonian species), based on macrofossil remains, and considered the latter three to be redeposited. He 
concluded that extremely severe climatic conditions existed in the periglacial zone at the time of sedimentation. To establish the role of redeposition, we dated separate species of fossil flora. The results, $18,100 \pm 500 \mathrm{BP}(\mathrm{Tln}-435)$ for the fir samples and 18,700 $\pm 1000 \mathrm{BP}$ (Tln-437) for birch, indicate no difference between the deposition of hypoarctic species and the presence of taiga and mixed forests.

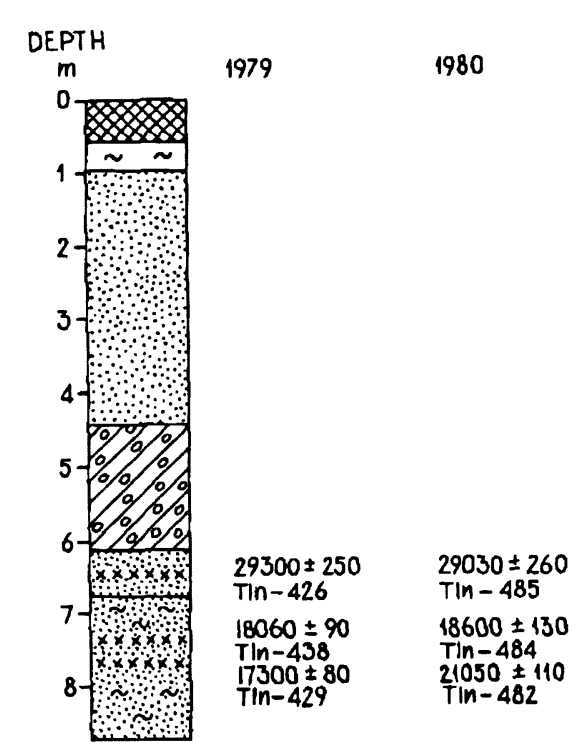

Fig. 4. ${ }^{14} \mathrm{C}$ dates from Brigitpole. For symbols, see Fig. 3.
Because we doubted the in-situ origin of organic detritus, we studied local erosional processes and collected samples for dating from $30 \mathrm{~m}$ up the Usvyachy River (e.g., Tln-36) from the Drichaluky section. Results demonstrated age inversion. The youngest date for the Usvyachy suite, $15,960 \pm 180 \mathrm{BP}$, makes the complex $1800 \mathrm{yr}$ "younger" than the earlier fixed age. A decade of studies has established a ${ }^{14} \mathrm{C}$ age of $17,800-20,300$ $\mathrm{BP}$ for the highest layer of detritus, and 16,000-24,500 $\mathrm{BP}$ for the lowest.

For more conclusive results on the genesis and age of lacustrine-alluvial and glacial deposits, we investigated a neighboring site on the Zapadnaya Dvina River at Brigitpole (Fig. 4) that is similar in geological structure to the Drichaluky section. Here, lacustrine-alluvial sediments with cryogenic disturbances are overlain by till and a variety of sands. We collected samples from layers of organic detritus in the lacustrine-alluvial sediments; ${ }^{14} \mathrm{C}$ dates from the uppermost layer $c a .40 \mathrm{~cm}$ below the basal till and from two layers, 120 and 130 $\mathrm{cm}$ below the first, yielded ages of 29,300 $\pm 300,18,060 \pm 90$ and 17,300 $\pm 80 \mathrm{BP}$, respectively.

\section{Lake Kubenskoye}

The western shore of Lake Kubenskoye is part of a glacial depression bordering on knob-and-ridge relief at a maximum elevation of 110-140 $\mathrm{m}$. The Kubenskoye structural depression, extended in the direction of glacial movement, enhanced the motion of the ice tongue behind the glacial front during the stage immediately preceding the formation of the Kirillovo-Byelozersky moraine ridges (Serebryanny 1978).

This area is located near the border of the Valdaian glaciation, on the southern end of Lake Kubenskoye along the Oloryev ridge, and is almost entirely buried under limnoglacial sediments. An important criterion in fixing the outer boundaries of the Late Valdaian glacier is the occurrence of till-covered Mid-Valdaian lacustrine and bog sediments. In the sections south of this border, the Mid-Valdaian deposits are not covered by till (Fig. 2).

The Valdaian glacial maximum was dated from the Kubensko-Kirillov section on the Puchka River. Markov (1939) stated that remains of polar flora, leaves of Dryas octopetala, Salix polaris, Betula nana and fruit of Cyperaceae (Carex) were found in the loam under the till. The pollen diagram, compiled from four samples from the uppermost till-covered loam, indicates a considerable amount of fir (up to $83 \%$ ) and a smaller amount of pine (up to $32 \%$ ). Such pollen spectra provide evidence of the development of dark coniferous taiga in this region, whereas carpological data fix tundra 
conditions. Markov (1939) believed that the lacustrine layers were deposited before the onslaught of the glacier, which left behind the upper till.

Ausländer, Arslanov and Homutova (1970) and Vigdorchik et al. (1970) studied a section on the Puchka River near the one described by Markov (1939). Remains of the following plants were found in the peat layer under the till: Dryas octopetala, Salix polaris, S. rotundifolia, S. nommularia Anders and Betula nana (Kolesnikova and Homutova 1971). Arslanov obtained two ${ }^{14} \mathrm{C}$ dates from the same layer: $21,410 \pm 150 \mathrm{BP}$ (LU-18B) and 21,880 $\pm 110 \mathrm{BP}$ (LU-18A). The pollen diagram of this section, compiled by V. I. Homutova, provides evidence that, in the lower part of the section (including the peat layer), fir (50-60\%) dominates the arboreal species, followed by pine, birch and alder. The occurrence of birch and alder increases in the upper levels, whereas fir constitutes not more than $20 \%$. Among herbs, the pollen spectra are dominated by sedge; mesophilous herbs are well represented. Wormwood and goosefoot concentration does not exceed $10-20 \%$, and only in the upper samples, constitutes $40 \%$. Spores of green mosses dominate all samples. Thus, there is a certain discrepancy between carpological and palynological data.

Ausländer, Chebotareva, Arslanov and others believe that these ${ }^{14} \mathrm{C}$ dates allow estimation of the age of the upper till and the maximum of Valdaian glaciation at 18,000-20,000 BP (Ausländer, Arslanov and Homitova 1970; Chebotareva 1977).

TABLE 2. ${ }^{14} \mathrm{C}$ Ages for Peat from Layer 4, Puchka River Section (Arslanov 1987)

\begin{tabular}{lll}
\hline Sample pretreatment & Age (yr BP) & Sample no. \\
\hline $\begin{array}{l}\text { 1. Peat with wood remains after standard chemical } \\
\text { treatment with } \mathrm{HCl} \text { and } \mathrm{NaOH}\end{array}$ & $15,320 \pm 110$ & LU-1194A \\
$\begin{array}{l}\text { 2. Fraction dissolved in } 2 \% \mathrm{NaOH} \text { at room tempera- } \\
\text { ture }\end{array}$ & $16,280 \pm 330$ & LU-1194B \\
$\begin{array}{l}\text { 3. Fraction dissolved in hot } 1 \% \mathrm{NaOH} \\
\text { 4. Same sample, peat fraction after standard } \\
\text { chemical treatment with } \mathrm{HCl} \text { and } \mathrm{NaOH}\end{array}$ & $15,880 \pm 150$ & LU-1194C \\
$\begin{array}{l}\text { 5. Same sample, wood fraction after standard chemi- } \\
\text { cal treatment with } \mathrm{HCl} \text { and } \mathrm{NaOH}\end{array}$ & $15,630 \pm 160$ & LU-1194E \\
\hline
\end{tabular}

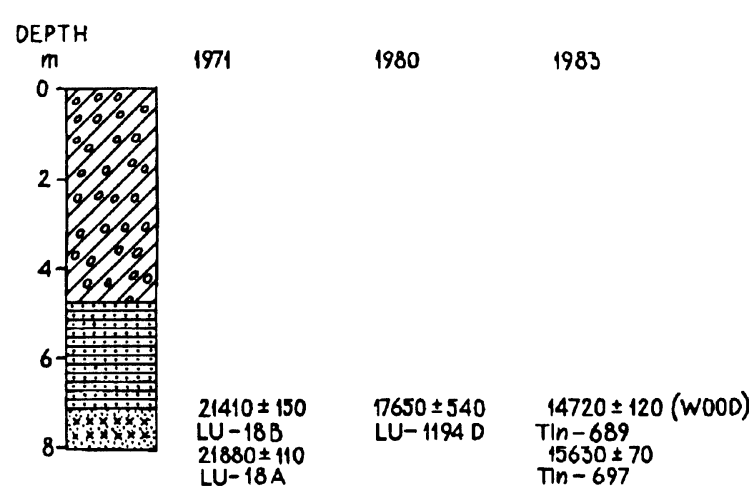

Fig. $5 .{ }^{14} \mathrm{C}$ dates from Puchka. For symbols, see Fig. 3.
Table 2 shows ${ }^{14} \mathrm{C}$ ages of peat in Layer 4; they were measured at the Geochronology Laboratory of the Research Institute of Geography, St. Petersburg University. Arslanov believes that $17,650 \pm 540$ (LU-1194D) is the most reliable date. From this sample, all organic additions $>2 \mathrm{~mm}$ were removed because they evidently contained younger roots and bark (Zarrina et al. 1986). In 1983, I. I. Krasnov and R. Rajamäe collected plant remains and peat from the same layers (Layer 4) and obtained dates of $15,630 \pm 70 \mathrm{BP}(\mathrm{T} \ln -697)$ and $14,720 \pm 120$ BP (Tln-698) (Fig. 5). 
A section first described by Markov (1939) is $12 \mathrm{~km}$ southeast of the Puchka River sites, on the the Chtchepinky River by Irkhino. This profile is similar to the Puchka section, although descriptions differ among authors. Markov believed that the till-covered loams of this profile were more or less synchronous with the peat in the Puchka section. Table 3 shows dates for peat Layer 6 from this section; they were measured at the Geochronology Laboratory of the Research Institute of Geography, St. Petersburg University. A ${ }^{14} \mathrm{C}$ age of $27,090 \pm 60 \mathrm{BP}$ (Tln-715) (Fig. 6), measured at the Tallinn Laboratory, was obtained from the same layer.

TABLE 3. ${ }^{14} \mathrm{C}$ Ages of Peat from Layer 6, Irkhino River Section (Arslanov 1987)

\begin{tabular}{lll}
\hline Sample pretreatment & Age (yr BP) & Sample no. \\
\hline $\begin{array}{l}\text { 1. Peat with wood remains after standard } \\
\text { chemical treatment with } \mathrm{HCl} \text { and } \mathrm{NaOH}\end{array}$ & $21,780 \pm 170$ & LU-1195A \\
$\begin{array}{l}\text { 2. Wood after standard chemical treatment } \\
\text { with } \mathrm{HCl} \text { and } \mathrm{NaOh}\end{array}$ & $22,380 \pm 680$ & LU-1195B \\
$\begin{array}{l}\text { 3. Peat after standard chemical treatment } \\
\text { with } \mathrm{HCl} \text { and } \mathrm{NaOH}\end{array}$ & $21,640 \pm 270$ & LU-1195C \\
\hline
\end{tabular}

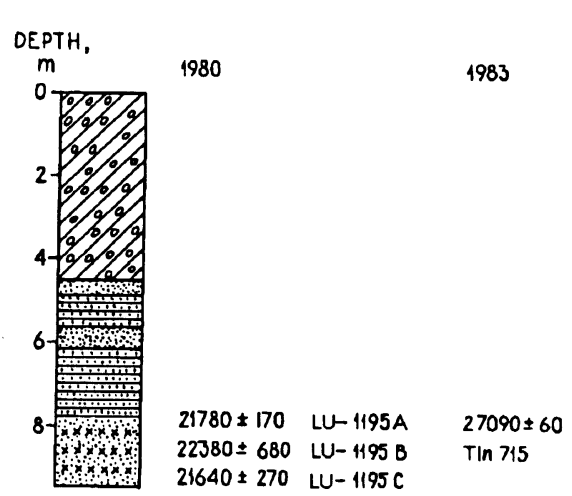

Fig. $6 .{ }^{14} \mathrm{C}$ dates from Irkhino. For symbols, see Fig. 3.

\section{Discussion}

The $18{ }^{14} \mathrm{C}$ dates, with the paleontological data of Velichkevich, allow us to interpret processes of lacustrine-alluvial and glacial sedimentation in the Drichaluky and Brigitpole sections. The normal age sequence is interrupted in 3 series of ${ }^{14} \mathrm{C}$ dates out of 5 , implying an allochthonous origin of the sediments. The upper part of the stratigraphic units was dated to $17.8-29.3 \mathrm{ka} \mathrm{BP}$, the bottom to $16-23.6 \mathrm{ka} \mathrm{BP}$.

Our geochronological data support Velichkevich (1973), who suggested the possibility of deposition of macrofossil remains of varying ages. Obviously, organic sedimentation in the floodplains of the Zapadnaya Dvina River valley occurred during glacial retreat, when organic remains were eroded from Mid-Valdaian deposits. Also, some detrital material probably originated from neighboring sections containing Mikulian sediments (Punning, Rajamäe and Hütt 1982). Because of mixing of in-situ and allochthonous organic detritus, a wide spectrum of sample ages is possible, of which the youngest date best reflects the accumulation time of the sediments. This means that alluvial deposits started to form not earlier than $16 \mathrm{ka}$ ago.

These data do not reflect the age of the Late Valdaian maximum. Biodetrital layers in lacustrinealluvial sediments were deposited after degradation of the ice shield. A relatively thin ice tongue in the Dvina-Kaspljane depression was isolated from the glacial massif, became "dead ice" and was covered by glacial sediments. An analog exists at Svalbard, where ice was covered by marine sediments at $8 \mathrm{ka} \mathrm{BP}$ and persists to the present.

With improving climatic conditions and intensive water erosion, the dead ice masses degraded and were covered by alluvial deposits during solifluction. The layers that we dated in the Drichaluky and Brigitpole sections formed as a result of these processes. During this interval, the margin of the continental ice shield retreated far north from the Surazha area. A similar process occurred in 
the formation of lacustrine-alluvial sediments in the sections near Lake Kubenskoye. This is supported by the fact that biodetrital material collected from the same layers at different times yields highly variable ${ }^{14} \mathrm{C}$ results. Botanical data show that the organic material is heterogeneous and consists of species that represent a completely different climate (Krasnov et al. 1986). This organic material is probably of periglacial and arctic derivation and was redeposited from neighboring sections with Mikulian (Eemian) interglacial flora.

As there are few sections with interstadial sediments suitable for ${ }^{14} \mathrm{C}$ dating on the East European Plain, dates from the Surazha and Kubenskoye profiles were widely used for estimating the age of the last glacial maximum. Voznyachuk (1973) claimed, for example, that the Late Weichselian glacial maximum occurred everywhere at $c a .17 \mathrm{ka}$ BP. However, the results obtained in our reinvestigation cause us to be skeptical. ${ }^{14} \mathrm{C}$ dates and paleobotanical analyses both indicate that the lacustrine sediments of the Mid-Weichselian ice-free period and the Late Weichselian glaciation contain fossils that were redeposited from older sediments, which considerably decreases the reliability of the ${ }^{14} \mathrm{C}$ results. Under conditions of redeposition, ${ }^{14} \mathrm{C}$ data indicate the maximum age of a given sediment layer.

Despite the abundance of ${ }^{14} \mathrm{C}$ dates, we remain uncertain of the age of the last glacial maximum in the northwest Russian Plain. Rather, we conclude that ${ }^{14} \mathrm{C}$ results reflect asynchrony in the development of separate ice tongues extending far from the glacial center.

\section{REFERENCES}

Arslanov, H. A. 1987 Radiocarbon: Geochemistry and Geochronology. Leningrad, Nauka: 300 p.

Arslanov, H. A., Voznyachuk, L. N., Velichkevich, F. Y., Mahnach, M. A., Kalechitz, E. G. and Petrov, G. S. 1971 The age of the maximum stage of the last glaciation in the region of River Dnepr and River Zap Dvina. Doklady Academii Nauk SSSR 196: 161-164.

Ausländer, V. G., Arslanov, H. A. and Homutova, V. I. 1970 On the Problem of Stratigraphy and Geochronology of Late Pleistocene Sediments in Kubensko-Suhansko Lowland and Neighboring Watershed Areas in Periodization and Geochronology of the Pleistocene. Leningrad: 92-95.

Chebotareva, N. S., ed. 1977 The Structure and Dynamics of the Ice Cover of the Last Glaciation in Europe. Moscow, Nauka: $143 \mathrm{p}$.

Chebotareva, N. S. and Makarycheva, I. A. 1974 The Last Glaciation in Europe and its Geochronology. Moscow, Nauka: 215 p.

Ilves, E., Liiva, A. and Punning, J.-M. 1974 The Radiocarbon Method and Its Application to Quaternary Geology and Archeology in Estonia. Tallinn: 230 p.

Kolesnikova, T. D. and Homutova, V. J. 1971 New data on the history of vegetation development during the Valdaian glaciation in the territory of Vologda District. Doklady Academii Nauk SSSR 196: 413-416.

Markov, K. K. 1939 Data on the stratigraphy of Quaternary sections in the basin of Upper Volga. Expedition to Verhnevolsk, Proceedings. Leningrad: 1-38.

Punning, M. K., Rajamäe, R. A. and Hütt, G. I. 1982 The age of lacustrine-alluvial sediments in sections of
Drichaluky and Brigitpole (N. Belorussia). Academy of Science of Estonia Proceedings in Geology 31: 15-20.

Rajamäe, R. and Putnik, H. 1981 Scintillation counting of ${ }^{14} \mathrm{C}$ in small amounts of carbon. In Isotopic and Geochemical Methods in Biology, Geology and Archaeology. Tartu: 118-120.

Serebryanny, L. R. 1978 The Dynamics of Ice Cover and Glaciation in the Late Quaternary Period. Moscow, Nauka: $270 \mathrm{p}$.

Velichkevich, F. Y. 1973 Quaternary Seed Flora in Belorussia and Adjoining Areas. Minsk: 131 p.

Vigdorchik, M. E., Ausländer, V. G., Doluhanov, P. M. and Znamenskaja, O. M. 1970 The new radiocarbon dates on lacustrine sediments in NW Russia and the geochronological scale of the last glaciation. In Proceedings of the Symposium on the History of Lakes. Vilnius: 5-32.

Voznyachuk, L. N. 1972 The age of maximal stage of Valdaian glaciation in NW USSR. Problems of Quaternary Geology. Riga: 29-43.

1973 On the stratigraphy and paleogeography of the Neopleistocene of Belorussia and adjoining territories. Problems of Quaternary Paleogeography of Belorussia. Minsk: 45-75.

Zarrina, E. P., Krasnov, J., Malahovski, D. B., Rajamäe, R. A. and Spridonova, E. A. 1986 The age of maximum distribution of the Late Pleistocene glacier on the NW Russian Plain. Isotope-Geochemical Investigations in the Baltic and Belorussia. Tallinn: 82103. 